\title{
COMPARATIVE FEEDING OF SEVERAL CELLULOSE BAITS BY THE SUBTERRANEAN TERMITE Reticulitermes flavipes (Kollar) (ISOPTERA: RHINOTERMITIDAE)
}

\author{
María José Munizaga ${ }^{1}$, y Jaime E. Araya ${ }^{1 *}$ \\ ${ }^{1}$ Facultad de Ciencias Agronómicas, Depto. Sanidad Vegetal, Universidad de Chile, Santa Rosa 11315, \\ Santiago, Chile. \\ * Author for correspondence E-mail: jaimearaya@yahoo.com
}

\section{RESUMEN}

Los cebos de material celulósico son importantes para detectar focos de infestación de la termita subterránea Reticulitermes flavipes (Kollar) (Isoptera: Rhinotermitidae). Se estudió la preferencia alimentaria de esta termita, entre madera de Pinus radiata L., cartón corrugado, papel absorbente, aserrín de pino radiata y papel roneo, por separado, en contenedores de PVC con sustrato de arena y agua destilada, y 100 termitas obreras cada uno, durante 10, 20, 30 y 40 días, con cuatro repeticiones por período. El consumo, en mg por termita al día, fue significativamente mayor en la madera de pino y el papel roneo que en cartón y el papel absorbente. El aserrín tuvo un consumo intermedio, con diferencias únicamente con la madera de pino. El consumo no presentó diferencias significativas entre los períodos de tiempo. La supervivencia de las termitas fue significativamente menor en cartón que en papel absorbente, y sin diferencias entre los demás materiales; $\mathrm{y}$ en períodos de $30 \mathrm{y}$ 40 días la supervivencia fue significativamente menor que en 10 y 20 días. La mayor supervivencia en el tratamiento con papel absorbente sugiere que un alimento nutricionalmente favorable puede consumirse menos cuando es la única alternativa, lo que indica que el consumo en pruebas sin elección no revela la preferencia alimenticia que puede ocurrir en el campo.

Palabras clave: Termita cebos, subterránea, preferencia alimentaria, cebos.

\begin{abstract}
Cellulose baits are important for the early detection of infestation by subterranean termites Reticulitermes flavipes (Kollar) (Isoptera: Rhinotermitidae). The feeding preferences of this termite were studied on Pinus radiata L. pinewood, corrugated cardboard, paper towel, pinewood sawdust, and roneo paper, set separately in PVC containers with a sand and distilled water substrate, each with 100 workers, during 10, 20, 30, or $40 \mathrm{~d}$, with four replicates per period. Consumption in mg/ termite/day was significantly greater on pinewood and roneo paper than on corrugated cardboard and paper towel. Pine sawdust had an intermediate consumption, while differences were observed only with pinewood. No significant differences in consumption were observed between the time periods. Termite survival was significantly lower on corrugated cardboard compared to paper towel, but similar to the other materials. In addition, the survival of $R$. flavipes was significantly lower at 30 and $40 \mathrm{~d}$ compared to the values observed at 10 and $20 \mathrm{~d}$. The higher survival of insects observed in the towel paper treatment suggests that the consumption of nutritionally favorable food may be lower when it is the only alternative. This indicates that consumption in no-choice tests does not reveal the food preference that may occur in the field.
\end{abstract}

Key words: Termite baits, subterranean, consumption, feeding, baits.

Received: 17 April 2018. Accepted: 23 July 2018. 


\section{INTRODUCTION}

Termites decompose wood and incorporate organic matter to the soil. However, they are a major problem, and some cause a great economic impact on wood worldwide (Eaton and Hale, 1993; Ripa and Luppichini, 2004). Since the arrival of the subterranean termite Reticulitermes flavipes (Kollar) (Isoptera: Rhinotermitidae) in Chile in 1986 (Morales-Ramos and Rojas, 2003), it has spread in the country (Ripa and Luppichini, 2004), affecting home quality and value (Morales-Ramos and Rojas, 2003; Su et al., 2006). As subterranean termites damage trees, they could eventually affect native vegetation and/or forest plantations (Ripa and Castro, 2001). In Santiago, R. flavipes develops in soils from -4 to $27^{\circ} \mathrm{C}$ and 6 to $36.7 \%$ humidity content (Ramírez and Lanfranco, 2001). In 1998, 80 infestation focuses were detected by INTEC (Instituto de Investigaciones Tecnológicas) and INFOR (Instituto Forestal) in 29 communes of Santiago, and in some areas of the Valparaiso Region. Further studies reported 56 focuses in the Metropolitan Region, with a rapid growth since 1995, and damage reaching US $\$ 15$ million (Karsulovic and Bozo, 2006).

Although subterranean termites preferentially consume wood decayed by certain fungi, they also damage healthy wood (Cornelius et al., 2002). In fact, they prefer to feed on some wood and a cellulose matrix with additives (MoralesRamos and Rojas, 2001a; 2003). Certain organic compounds induce preference or increase consumption of cellulosic food (Reinhard et al., 2002a; 2002b; Cornelius, 2003; Cornelius and Lax, 2005; Swoboda et al., 2004).

Toxic baits, used alone or combined with chemical barriers, are a good management solution, but they are costly and many of them are not available in Chile. In this sense, it is necessary to search for efficient, economical and environmentally-friendly bait alternatives (Munizaga, 2008). In general, commercial baits do not use attractants (Cornelius and Lax, 2005), and those existing are based on termite foraging and food search. Termites have feeding preferences and show differences in consumption levels for certain woods (Morales-Ramos and Rojas, 2001a). Therefore, finding preferred foods, feeding stimulant substances or other toxic substances for $R$. flavipes to incorporate into baits would result in an improved monitoring and control of this pest.

The objective of this study was to compare feeding preferences between several cellulose materials, and to evaluate them as inexpensive baits for R. flavipes.

\section{MATERIALS AND METHODS}

This study was developed with $R$. flavipes termites collected from a colony reared at 23$27^{\circ} \mathrm{C}$, in the Automation Laboratory, Department of Wood Engineering, College of Forest and Nature Conservation Sciences, University of Chile, Santiago, Chile.

PVC containers with a $4: 1$ substrate mixture of $200 \mathrm{~mL}$ sand and $50 \mathrm{~mL}$ water were used, each with a group of 100 termite workers. To avoid handling stress, a $7 \mathrm{~d}$ adapting period was set before evaluating the materials, during which the termites were reared with pinewood. Five cellulose food materials were evaluated: pinewood blocks, corrugated cardboard, paper towel, pinewood sawdust, and roneo paper (all with 16 replicates). To determine the variation of consumption over time, the tests lasted 10, 20, 30, or $40 \mathrm{~d}$, with four replicates per period. Roneo paper was added in the longest bioassay, with six replicates.

For the tests, the $4 \times 2 \times 0.5 \mathrm{~cm}$ wood pieces and the pinewood sawdust were obtained from the same wood material to avoid differences. The wood pieces were set paired with a rubber band. The sawdust was placed in an open container buried at the substrate level. The corrugated cardboard, paper towel, and roneo paper were set slightly rolled and inside PVC tubes. As size, compaction and composition of the bait affect consumption significantly (Evans and Gleeson, 2006), each treatment used $9-11 \mathrm{~mL}$ feed.

To determine dry weight, materials were weighed, placed in an oven at $55^{\circ} \mathrm{C}$ for $48 \mathrm{~h}$, and dehydrated for $30 \mathrm{~min}$ at $30 \mathrm{~mm} \mathrm{Hg}$ vacuum. Then their normal humidity was restored for use in the bioassays. Each container had its corresponding food, which was slightly buried. The containers were left in a laboratory termite colony at $25 \pm$ $2^{\circ} \mathrm{C}$, and weighed once a week to verify humidity recovery; the container weight and initial amount of substrate were previously determined.

Termites in the treatments and those alive in each container were counted at the end of each bioassay. The materials were cleaned with a hair brush, weighed and set in the oven for 48 $\mathrm{h}$. Then they were dehydrated for $30 \mathrm{~min}$ at 30 $\mathrm{mm} \mathrm{Hg}$ vacuum, and weighed to obtain the final dry weight, which was taken from the initial dry weight to obtain total consumption in the period. Humidity content was also measured at the end of the test.

The response variables were the number of termites surviving and the average consumption per termite in $\mathrm{mg}$ at 10, 20, 30, and 40 days. Termite mortality was assumed constant and linear. The average feeding of a termite (AFT) was 
calculated with the formula: AFT $=\mathrm{mg}$ consumed per group during the bioassays. As the initial and final numbers of termites were known, the previous formula is equivalent to AFT $=\mathrm{C}^{*} 2 /[$ (in $+\mathrm{fn})^{*} \mathrm{~d}$ ], where $\mathrm{C}=$ total consumption, in = initial termite $\mathrm{n}^{\mathrm{o}}, \mathrm{fn}=$ final termite $\mathrm{n}^{\circ}$, and $\mathrm{d}=$ days of the experiment (Hadi et al., 2014).

A completely randomized design was used. Data were analyzed using an ANOVA with the plots divided by food and time (subplots) to detect interactions. Means were compared with the Tukey test at $95 \%$.

\section{RESULTS AND DISCUSSION}

The analysis of termite consumption per day revealed significant differences between treatments (Table 1). Pinewood and roneo paper were more highly consumed than corrugated cardboard and paper towel. Pinewood sawdust and roneo paper were the most highly consumed treatments. Pinewood sawdust was different from all the other materials, while the latter was different from corrugated cardboard and paper towel.

However, mean termite consumption at 10, 20, 30 , and 40 days did not vary significantly between treatments (Table 2).

Pinewood has been used as a control in several bioassays on termite feeding preferences. As it is inexpensive, abundant and commonly found in buildings in Chile, it was also used in this study. In fact, it was considered useful to include pinewood as a reference to compare with the other materials offered to the insect, and also to determine if it should be included in the development of trap baits.

In another study, subterranean termites Coptotermes formosanus Shiraki consumed a cellulose matrix with nutritive supplements and additives more than Pinus taeda L. yellow pinewood since the matrix was more nutritious for them (Hapukotuva and Grace, 2011). Similar results were observed in several wood bioassays conducted by Morales-Ramos and Rojas (2001a; 2003). This suggests that pinewood and roneo paper are more nutritious for termites than corrugated cardboard and paper towel. Both of them could lack elements that are necessary for $R$. flavipes and that are found in pinewood and roneo paper.

Unlike the other material evaluated, corrugated cardboard is a paper-based material that has lost almost all the cellulose (Vitis, 2002), and this could be related to its low consumption. In this sense, paper towel has a high percentage of cellulose and also a high consumption. It is also possible that compounds used in cardboard inhibit termite feeding; cardboard is treated with adhesive to give it moisture resistance. Conversely, roneo paper has very little chemical additives and gluing.

Table 1. Average consumption ( \pm SD) of the food materials evaluated, and mean value of surviving R. flavipes ( $\pm \mathrm{SD})$.

\begin{tabular}{llc}
\hline Treatments & $\begin{array}{c}\text { Average consumption } \\
\text { (mg/termite/day) }\end{array}$ & $\begin{array}{c}\text { Mean value of surviving } \\
\text { R. flavipes }\end{array}$ \\
\hline Pinewood blocks & $0.07642 \pm 0.05 \mathrm{c}$ & $83.75 \mathrm{ab} \pm 7.05$ \\
Roneo paper & $0.07370 \pm 0.04 \mathrm{bc}$ & $79.50 \mathrm{a} \pm 6.86$ \\
Pinewood sawdust & $0.06013 \pm 0.03 \mathrm{ab}$ & $88.56 \mathrm{~b} \pm 6.93$ \\
Corrugated cardboard & $0.05056 \pm 0.02 \mathrm{a}$ & $83.63 \mathrm{ab} \pm 5.85$ \\
Paper towel & $0.04959 \pm 0.02 \mathrm{a}$ & $83.33 \mathrm{ab} \pm 6.02$ \\
\hline
\end{tabular}

Means with different letters are significantly different ( $\mathrm{P} \leq 0.05$ in a Tukey test).

Table 2. Mean consumption per termite $( \pm S D)$ and mean value of surviving termites $( \pm S D)$ at 10,20 , 30 , and 40 days.

\begin{tabular}{ccc}
\hline Days & A verage consumption (mg/termite/day) & $\begin{array}{c}\text { Mean value of surviving } \\
\text { termites }\end{array}$ \\
\hline 10 & $0.06073 \pm 0.02 \mathrm{a}$ & $88.97 \pm 9.13 \mathrm{~b}$ \\
20 & $0.06279 \pm 0.02 \mathrm{a}$ & $87.37 \pm 9.20 \mathrm{~b}$ \\
30 & $0.06325 \pm 0.03 \mathrm{a}$ & $80.57 \pm 7.83 \mathrm{a}$ \\
40 & $0.06156 \pm 0.02 \mathrm{a}$ & $78.12 \pm 7.35 \mathrm{a}$ \\
\hline
\end{tabular}

Means with the same letter were significantly similar $(\mathrm{P} \leq 0.05)$ in a Tukey test. 
Some nitrogenous compounds are preferred or induce a greater consumption by termites (Reinhard et al., 2002a; Swoboda et al., 2004). For example, the termite Zootermopsis nevadensis (Hagen) has a food selection mechanism by which the winged founders set the colonies on woods rich in nitrogen (Thorne and Traniello, 2003).

Pine sapwood contains nitrogen compounds that could induce consumption, which are lost during the pulp process to obtain paper. Although this would not explain the high consumption of roneo paper, it is not strange that this material did not present a significant consumption difference with pinewood, as its chemical composition is quite similar.

Roneo paper is obtained mainly from Pinus radiata wood, while towel paper is obtained from Eucalypt spp. The fact that termites would prefer pinewood fibers to those from eucalypts may be related to their content of cellulose or other non-extractable compounds. According to Peralta et al. (2003), stakes from Pinus sp. are significantly preferred by subterranean termites to those from eucalypts. However, Atkinson et al. (1992) indicated that eucalypts are particularly susceptible to termites, while Rojas (2005) found that Reticulitermes spp. preferred Eucalyptus to pinewood.

Unlike wood, towel paper has no resins, very little lignin and hemicellulose, and part of the cellulose has been degraded during clearing, decreasing glucose component units (J.T. Karsulovic, Universidad de Chile, Facultad de Ciencias Forestales, Departamento de Silvicultura, personal communication, 2005).

Significant differences were found between pine sawdust with pinewood. The structure of the particles could have hindered food access; the building of a gallery was observed through sawdust, reaching the end of the container, while galleries in pinewood had branches. Gallery building in sawdust is probably more difficult because of the air spaces that could hinder their use as food.

Termites generally prefer easily obtained cellulose. Suiter et al. (no publication date) indicated the following preference order: single cellulose fibers $>$ paper $>$ cardboard $>$ softwood $>$ hardwood, but these preferences do not coincide with our results.

Food density affects termite feeding. In Morales-Ramos and Rojas (2005), wood consumption by C. formosanus was significantly greater in P. taeda than birch (Betula spp.), which could be due to the relative density of those materials. In R. flavipes, Arango et al. (2006) found an inverse relation between mass consumed and relative density (density/water density) in tropical hardwoods, and a slight positive relation in softwood species. However, a study on wood consumption of eucalypts and radiata pine conducted by Peralta et al. (2004) did not relate it to its density. Thus, there is no clear relation between wood density and consumption, and this factor alone is insufficient to explain termite consumption.

Evans and Gleeson (2006) found that food composition, compaction, and size affect feeding significantly, and that large compacted paper baits were more effective than small compacted paper ones.

For practical uses, to develop toxic baits it is important to find materials that are more consumed in biomass removed than in volume, for a greater ingestion of the toxic ingredient. An also, they must be preferred to other alternatives available. Our no-choice laboratory study cannot provide conclusions on the preference that may occur in the field.

In the laboratory, C. formosanus presented a greater consumption of wood blocks with greater moisture content (Delaplane and La Fage, 1989). In this study, the humidity content of the cellulose materials was determined at the beginning and at the the end of each test, but not during them, in order to avoid destroying the galleries. This is why no regression was performed between humidity content and food consumption.

Peralta et al. (2004) indicated that many factors affect wood consumption by termites, which can be applied to the materials evaluated herein. Differences in consumption could be due to factors, such as the main wood used to produce the material, its cellulose content and other beneficial compounds for the termites, which include hardness, presence of toxic substances or feeding inhibitors, and water content of the food.

The exposure of $R$. flavipes nymphs to pinewood blocks during $24 \mathrm{~h}$ did not increase feeding nor the aggregation of workers to the wood, although these two factors were not part of this study.

The number of termites surviving at the end of the bioassay was significantly different between corrugated cardboard and paper towel (Table 1). The lowest and highest survival of insects was recorded in corrugated cardboard and paper towel, respectively. Pinewood, pine sawdust, and roneo paper showed no differences when compared to cardboard or paper towel, with no differences between them.

The greatest survival in the towel paper treatment suggests that a nutritionally favorable food may be less consumed when it is the only alternative, indicating that consumption in nochoice tests does not reveal the food preference that may occur in the field. 
Other studies with several types of wood have found increased mortality accompanied with less feeding, indicating the presence of toxic substances or a lower-quality diet (Kenneth and Yamamoto, 1994; Morales-Ramos and Rojas, 2001b). The adhesive used between the sides of corrugated cardboard could have been toxic, thus increasing mortality. Similarly, the low cellulose content of cardboard could have affected termite survival because it did not provide enough nutrition.

The greatest survival in paper towel, plus its high cellulose content, would support that its low consumption did not occur because it is unfavorable for termites, but because they did not need to consume a great amount of food to supply their energy requirements.

Differences also occurred between the time periods, with survival decreasing with cumulative time (Table 2). The 10 and $20 \mathrm{~d}$ periods were different from those of 30 and $40 \mathrm{~d}$. However, no significant differences were found between 10 and $20 \mathrm{~d}$ or between 30 and $40 \mathrm{~d}$.

The increase of mortality in time could be due to an increase in natural mortality because of a low initial number of individuals. In a study with $C$. formosanus, the survival of colonies from 90 to 180 $\mathrm{d}$ and from 90 to $360 \mathrm{~d}$ was related to the number of workers in colonies aged $90 \mathrm{~d}$, indicating that survival depends on worker presence (MoralesRamos and Rojas, 2003).

\section{CONCLUSIONS}

$R$. flavipes consumed significantly more pinewood and roneo paper than towel paper, corrugated cardboard and pinewood sawdust.

\section{ACKNOWLEDGMENTS}

This study was funded by Fondecyt project 1040726.

\section{LITERATURE CITED}

Arango, R., F. Green, K. Hintz, P. Lebow, and R. Miller. 2006. Natural durability of tropical and native woods against termite damage by Reticulitermes flavipes (Kollar). International Biodeterioration \& Biodegradation 57:146150.

Atkinson, P.R., K.M. Nixon, and M.J.P. Shaw. 1992. On the susceptibility of Eucalyptus species and clones to attack by Macrotermes natalensis Haviland (Isoptera: Termitidae). Forest Ecol. Manag. 48(1-2):15-30.
Cornelius, M. 2003. Evaluation of semiochemicals as feeding stimulants for the Formosan subterranean termite (Isoptera: Rhinotermidae). Sociobiology 41(3):583-591.

Cornelius, M., D. Daigle, W. Connick, Jr., A. Parker, and K. Wunch. 2002. Responses of Coptotermes formosanus and Reticulitermes flavipes (Isoptera Rhinotermitidae) to three types of wood rot fungi. J. Econ. Entomol. 95:121-128.

Cornelius, M., and A. Lax. 2005. Effect of summon preferred food source on feeding, tunneling, and bait station discovery by the Formosan subterranean termite (Isoptera: Rhinotermitidae. J. Econ. Entomol. 98(2):502508.

Delaplane, K., and J. La Fage. 1989. Preference for moist wood by the Formosan subterranean termite (Isoptera: Rhinotermitidae). J. Econ. Entomol. 82(1):95-100.

Eaton, R.A., and M.D.C. Hale. 1993. Wood decay, pests and protection. 546 p. Chapman \& Hall, New York, USA.

Evans, T., and P. Gleeson. 2006. The effect of bait design on bait consumption in termites (Isoptera: Rhinotermitidae). Bull. Entomol. Res. 96(1):85-90.

Hadi, Y.S., A. Arinana, and M.Y. Massijaya. 2014. Feeding rate as a consideration factor for successful termite wood preference tests. Wood Fiber Sci. 46(4):590-593.

Hapukotuva, N.H., and J.K. Grace. 2011. Preferences of Coptotermes formosanus Shiraki and Coptotermes gestroi (Wasmann) (Blattodea: Rhinotermitidae) among three commercial wood species. Insects 2(4): 499508.

Karsulovic, T., y A. Bozo. 2006. Aunando esfuerzos para enfrentar la plaga de termitas subterráneas en la Región Metropolitana. Ambiente Forestal (Chile) 1(2):49-54.

Kenneth, G., and R. Yamamoto. 1994. Natural resistance of Alaska-cedar, redwood, and teak to Formosan subterranean termites. Forest Products Journal 44(3):41-45.

Morales-Ramos, J., and G. Rojas. 2001a. Bait matrix for delivery of chitin synthesis inhibitors to the Formosan subterranean termite (Isoptera: Rhinotermitidae). J. Econ. Entomol. 94(2):506-510.

Morales-Ramos, J., and G. Rojas. 2001b. Nutritional ecology of the Formosan subterranean termite (Isoptera: Rhinotermitidae): feeding response to commercial wood species. J. Econ. Entomol. 94(2):516-523. 
Morales-Ramos, J., and G. Rojas. 2003. Nutritional ecology of the Formosan subterranean termite (Isoptera: Rhinotermitidae): growth and survival of incipient colonies feeding on preferred wood species. J. Econ. Entomol. 96(1):106-116.

Morales-Ramos, J., and G. Rojas. 2005. Wood consumption rates of Coptotermes formosanus (Isoptera: Rhinotermitidae): a three year study using groups of workers and soldiers. Sociobiology 45(3):707-719.

Munizaga, M.J. 2008. Estudio de alimentación $\mathrm{y}$ de sustancias tóxicas potenciales para Reticulitermes flavipes (Kollar) (Isoptera: Rhinotermitidae). 48 p. Memoria Ingeniero Agrónomo. Universidad de Chile, Facultad de Ciencias Agronómicas, Santiago, Chile.

Peralta, R.G., E.B. Meneses, A.C. Carvalho, and E. Aguilar-Meneces. 2003. Feeding preference of subterranean termites for forest species associated or not to a wood-decaying fungi. Floresta Ambient. 10(2):58-63.

Peralta, R.G., E.B. Meneses, A.C. Carvalho, and E. Aguilar-Meneces. 2004. Wood consumption rates of forest species by subterranean termites (Isoptera) under field conditions. Árvore 28(2):283-289.

Ramírez, C., y D. Lanfranco. 2001. Descripción de la biología, daño y control de las termitas: especies existentes en Chile. Bosque 22(2):7784.

Reinhard, J., M.J. Lacey, F. Ibarra, F.C. Schroeder, M. Kaib, and M. Lenz. 2002a. Hydroquinone: a general phagostimulating pheromone in termites. J. Chem. Ecol. 28(1):1-14.

Reinhard, J., M.J. Lacey, and M. Lenz. 2002b. Application of the natural phagostimulant hydroquinone in bait systems for termite management (Isoptera). Sociobiology 39(2):213-229.
Ripa, R., y L. Castro. 2001. Termitas, una plaga estructural en Chile. 9 p. INIA, Centro Experimental de Entomología La Cruz, Quillota, Chile.

Ripa, R., y M. Luppichini. 2004. Termitas de importancia económica en Chile. Tierra Adentro (Chile) 59 (nov.-dic.): 42-51.

Rojas, N. 2005. Termita subterránea: Identificación y preferencias alimentarias. $58 \mathrm{p}$. Memoria Ingeniero en Maderas. Universidad de Talca, Escuela de Ingeniería en Industrias de la Madera, Talca, Chile.

Su, N., W. Ye, R. Ripa, R. Scheffrahn, and R. Giblin-Davis. 2006. Identification of Chilean Reticulitermes (Isoptera: Rhinotermitidae) inferred from three mitochondrial gene DNA sequences and soldier morphology. Ann. Entomol. Soc. Am. 99(2):352-363.

Suiter, D., S. Jones, and B. Forschler. No publication date. Biology of subterranean termites in the eastern United States. University of Georgia Bulletin 1209. 13 p. In http://secure.caes.uga. edu/extension/publications/files/pdf/B $\% 20$ 129-4PDF (Accessed Sept. 2016).

Swoboda, L.E., D.M. Miller, R.J. Fell, and D.E. Mullins. 2004. The effect of nutrient compounds (sugars and amino-acids) on bait consumption by Reticulitermes spp. (Isoptera: Rhinotermitidae). Sociobiology 44(3):547-563.

Thorne, B., and J. Traniello. 2003. Comparative social biology of basal taxa of ants and termites. Annu. Rev. Entomol. 48:283-306.

Vitis, M. 2002. Evaluación comparativa de papeles nacionales e importados en el mercado del sector embalaje. 73 p. Memoria Ingeniero Forestal. Universidad de Chile, Escuela de Ciencias Forestales, Santiago, Chile. 